\title{
Almond and peanut flours suppelmented with iron as potential ingredients to develop gluten-free cookies
}

\author{
Farinhas de amêndoa e amendoim suplementadas com ferro como \\ ingredientes potenciais para desenvolvimento de biscoitos sem glúten
}

\author{
Daniel GRANATO*1, Luciana de Souza Neves ELLENDERSEN ${ }^{2}$
}

\begin{abstract}
Brazil is the second biggest worldwide producer of cookies and there are many varieties in the market; however, only a few are gluten-free. The objectives of this work were to formulate two gluten-free cookies added with iron, peanut or almond, and analyze their physicochemical, chromatic and sensory properties. Moisture, instrumental color $\left(L^{*}, a^{*}, b^{\star}\right.$ and $\left.C^{\star}\right)$, ash, proteins, lipids, iron, carbohydrates (estimated by difference), and water activity were determined. The acceptance of the products was assessed by 115 untrained taste panelists using a five-point hedonic scale. The data collected from the physicochemical analyses were submitted to Levene's, ANOVA, and Tukey's tests, which showed statistical difference $(\mathrm{p}<0.05)$ in all the attributes for centesimal composition, water activity, and color of the cookies. Peanut and almond cookies could be considered sources of iron once they presented at least $15 \%$ of the daily recommended value of intake. They also garnered acceptance indexes of 80 and $85 \%$, respectively, concluding that both formulations developed in this study were source of iron and contained high concentration of lipids and proteins with great sensory acceptance, suggesting their potential consumption by gluten-intolerants.

Keywords: cookies; almond; peanut; sensory evaluation; celiac disease.
\end{abstract}

\section{Resumo}

O Brasil é o segundo maior produtor de biscoitos do mundo e possui muitas variedades no mercado, entretanto, poucos são destituídos de glúten. O objetivo deste trabalho foi formular dois biscoitos sem glúten: um de amendoim e outro de amêndoa adicionados com ferro e analisar suas propriedades físico-químicas e sensoriais. Os parâmetros físico-químicos avaliados foram: umidade, cor $\left(L^{\star}, a^{\star}, b^{\star} \mathrm{e} C^{\star}\right)$, cinzas, proteínas, lipídios, ferro, carboidratos (estimados por diferença) e atividade de água. A aceitação dos produtos foi testada por 115 provadores não treinados que utilizaram uma escala hedônica de cinco pontos. Os dados coletados foram submetidos aos testes de Levene, de ANOVA e de Tukey, que mostraram a diferença estatística $(\mathrm{p}<0,05)$ em todos os atributos da composição centesimal, atividade de água e da cor dos biscoitos desenvolvidos. Os biscoitos de amendoim e de amêndoa apresentaram ferro em uma concentração que faz com que possam ser considerados fonte (pelo menos 15\% IDR). Apresentam também índice de aceitação de $80 \%$ e $85 \%$, respectivamente, concluindo que ambas as formulações desenvolvidas neste estudo apresentaram satisfatórias quantidades de ferro em sua composição e elevados teores de lipídios e proteínas, com elevada aceitação sensorial, sugerindo seu consumo potencial por pessoas intolerantes ao glúten.

Palavras-chave: biscoitos; amendoim; avaliação sensorial; doença celíaca.

\section{Introduction}

Cookie production has occurred since the Rock Age and its formulations and processing have been perfected continuously (PARRA, 2003). In accordance with Brasil (2005), cookies are produced by kneading and baking dough prepared from flour and/or starch, fermented or not, containing other nourishing substances. Flour can be derived from fruits, leaves, cereals, tubers, and other hortalices. The term 'cookie' is generally followed by the substance that characterizes it such as honey, carrot, chocolate etc. Other ingredients can also be used to prepare cookies to improve their physical, nutritional, sensory, or technological properties such as enzymes, colorings, vitamins, minerals, fibers and flavorings (MORETO, 1999).

Brazil is the second worldwide cookie producer followed by the United States that leads the ranking. In Brazil, there are 400 cookie industries and this sector registered in 2004 a total production of 1.080 tons. In 2007 this number increased to 1.131 tons, summing up an income of $\mathrm{R} \$ 7.42$ billion and a total export of more than US\$ 91.6 million (SIMABESP, 2008). These numbers indicate that Brazilian cookies are competitive in the international market due to their quality and acceptance. The average consumption of cookies, per person, in Brazil, has grown in the last five years suggesting that these products present a demanding market (ALVES; GROSSMANN, 2002).

Although many types of cookies and snacks have been developed over the last decades, few are gluten-free. Thus, the development of new products for celiacs, people with intolerance to gluten, and for those allergic to cow milk and to phenylketonurics and other ingredients has become necessary.

Recebido para publicação em 22/10/2007

Aceito para publicação em 29/8/2008 (002945)

1 Universidade Federal do Paraná - UFPR, Programa de Pós-Graduação em Tecnologia de Alimentos, Curitiba - PR, Brasil, E-mail: danigranato@gmail.com

2 Universidade Federal do Paraná - UFPR, Doutorado em Processos Biotecnológicos, Curitiba - PR, Brasil

${ }^{*}$ A quem a correspondência deve ser enviada 
This innovation demands multidimensional measures to guarantee the product's quality, and in this context, sensory tests, physical and chemical evaluations are a real and sufficient option to certify the absence of non-desirable components in the final product (NEVES, 2005).

Celiac disease is an enteropathy of the small intestine and which is dependent on an immunological process that can appear during childhood or adult life, when a permanent intolerance to gluten is developed (MURCH; WALKER-SMITH, 1995). Gluten is a set of proteins found in wheat, barley, rye, oats, and in some other cereals, and it forms the dough due to its unique cohesive and elastic properties, which are important technological features to produce cookies, bread, cakes and other bakery products (WALL; HUEBNER, 1981). Nevertheless, celiacs can not consume foods that contain this protein otherwise many symptoms can be developed such as weakness, loss of weight, and diarrhea due to bad absorption of nutrients in the small intestine.

One of the most important steps in the improvement of food quality in the last forty years is represented by food fortification, a way to correct a nutrient deficiency balancing the nutritional profile or restoring nutrients lost in the process (CREDIDIO, 2005). Moreover, food fortification can be an economical, flexible, and socially acceptable way to improve the nutrient intake of groups at risk in order to ensure nutritional adequacy of the diet (HOFFPAUER; WRIGHT, 1994) being an option by which people have access to milled or processed food (MASON et al., 2001). A great variety of foods have been enriched with substances that bring some health benefits: cookies produced with Saccharomyces cereviseae extract, rich in folate and other B vitamins (SANTUCCI; ALVIM; FARIA, 2003), cookies fortified with retinyl acetate (BUTT et al., 2007), milk casein (KRUGER et al., 2003), dietary fibers that help in the regulation of the gastrointestinal flow (MATIAS et al., 2005; ÖZTÜRK et al., 2002; SILVA, 1997), vitamin C and wheat germ with antioxidant properties (BILGIÇLI; İBANOG; HERKEN, 2007; TORRES; LOBO; SATO, 1995), vegetal proteins (MARTIN et al., 2007) and hydrolyzed proteins (SILVA et al., 2007) that increase the nutritional value of many food products. Notwithstanding, the addition of minerals in flours/starches for production of bread and cookies had been also investigated (TORRES; LOBO; SATO, 1996; SCABIO; GRANATO; FERRARI, 2005).

Iron deficiency is the most common nutritional disorder in the world, being prevalent in developing countries such as Brazil, and also in wealthy countries. Due to their nutritional requirements, the most affected groups are children, teenagers, and women (WHO, 2008). Few foods contain iron in considerable amount; moreover just a small dose is absorbed by the organism. Hence, food fortification has been identified as one of most effective and sustainable ways of controlling iron deficiency in populations (INACG, 1977).

Studies have shown that the iron enrichment of cookies and other food products is a viable and cheap way to prevent, and even to become a source of such element in the diet of convalescent people with anemia (BOCCIO; MONTEIRO, 2004). Peanut and almond do not contain relevant quantity of iron (TACO, 2006), thus, the enrichment of cookies processed with these ingredients leads to the improvement of their nutritional qualities.
Identifying the presence or absence of small differences in odor, flavor, texture, or appearance in the final product is very important to keep and control its quality. Sensory tests can be used to identify such features, which cannot be verified by other analytical procedures. Among these evaluations, acceptance tests stand out because they reflect the degree that consumers like or dislike the final product, so it has frequently used by food industries to test new ingredients and formulations before marketing (CAVALHEIRO et al., 2001). Color is one of the most important attributes of food products since it is an indicator of the cooking degree, aesthetics, and freshness. It is also the first characteristic to attract consumers' attention; therefore, it greatly influences their preferences (HUTCHINGS, 1999). Therefore, color is considered a major feature for the assessment of food product quality and in 1977 Cheftel and Cheftel (1977) proposed to measure it at the surface of crackers and cookies using reflectance due to the importance of this feature for their initial acceptability (AMEUR et al., 2007).

Data that regard the development of gluten-free cookies with almond and/or peanut are absent in the Brazilian literature and there is an ongoing demand for creating new options for gluten-intolerant consumers. Hence, this work is aimed at developing and evaluating the physicochemical, chromatic and sensory characteristics of gluten-free peanut or almond cookies, supplemented with iron, to generate new sources of these types of products to the celiacs.

\section{Materials and methods}

\subsection{Development of cookies' formulations}

The ingredients used in the formulations included egg white, commercial sucrose, UHT whole milk cream (with $25 \%$ total lipids), toasted peanut (Arachis hypogaea, Fabaceae) and almond (Prunus dulcis, Rosaceae), milled and turned into flour using a multiprocessor. Iron (food grade) was also used in the concentration of $15 \%$ of the daily recommended value (DRV) in a portion of $100 \mathrm{~g}$ of cookie. The concentration values of the ingredients per $100 \mathrm{~g}$ of final cookies were: peanut or almond (44.5 g), sucrose (43.5 g), UHT whole milk cream (6 g), egg white $(5,9 \mathrm{~g}), \mathrm{FeSO}_{4} .7 \mathrm{H}_{2} \mathrm{O}\left(3 \cdot 5 \cdot 10^{-3} \mathrm{~g}\right)$, and TBHQ $\left(2 \cdot 0 \cdot 10^{-4} \mathrm{~g}\right)$.

The cookies were prepared by the continuous mixture of the raw materials, previously weighed in analytical scale, rolling and pressing the dough with a metallic cylinder and a square of PVC, with dimensions $30 \times 30 \times 0.8 \mathrm{~cm}$, in a way that all the cookies presented the same thickness until it reached $3.0 \mathrm{~cm}$ diameter. The cookies were then baked for eight minutes at monitored temperature of $180 \pm 2{ }^{\circ} \mathrm{C}$. After that, they were cooled in room temperature $\left(23^{\circ} \mathrm{C}\right)$ and conditioned in LDPE packing until analyses.

\subsection{Physicochemical characterization}

Before analyzing the samples, the cookies were triturated and homogenized according to the standards set by the Instituto Adolf Lutz (2005) and the procedures were carried out in triplicate. The physicochemical parameters analyzed were: ashes, moisture, total lipids, and proteins using the conversion 
factors for almond and peanut proposed by USDA (2003) and also carbohydrates (estimated by difference); all according to AOAC (2000). Total energy was calculated multiplying the percentages of proteins, carbohydrates and total lipids by their respective Atwater's factors (4, 4 and $9 \mathrm{kcal} / \mathrm{g}$ ) (OSBORNE and VOOGT, 1986). The iron content was measured and quantified by flame atomic absorption spectrometry using the equipment model SpectrAA-200 (Varian, Mulgrave, Australia) according to AOAC (2000). The conditions of this analysis were: manual injection of samples, air/acetylene, wavelength of $372 \mathrm{~nm}$, slit width of $0.1 \mathrm{~nm}$, and calibration curve: $\mathrm{Y}=0.099 \mathrm{x}+0.044$, with $\mathrm{R}^{2}=0.9967$.

\subsection{Colorimetric analysis}

Instrumental color (CIELAB space) of the samples was measured in terms of the $L^{*}, a^{*}, b^{*}$ values using a spectrophotometer (Model D25L-2, Hunter Assoc. Laboratory, Reston, VA, USA) with D65 optical sensor, $0^{\circ}$ geometry and $10^{\circ}$ angle of vision. Chromaticity $\left(C^{*}\right)$, which measures the color intensity, was calculated by $C^{\star}=\left(a^{* 2}+b^{* 2}\right)^{1 / 2}$. $L^{*}$ is the lightness factor that indicates how light or dark the sample is; $a^{*}$ and $b^{*}$, the chromaticity coordinates, represent the red(+)/green(-) and yellow(+)/blue(-) color attributes (MARTIN et al., 2007). Prior to measuring the color of the cookie samples, the spectrophotometer was calibrated using black and white reference standard ceramic plates $(X=78.9$, $\mathrm{Y}=83.9, \mathrm{Z}=88.9$ ). Samples were placed in a clear glass Petri dish, and color measurements were performed six times.

\subsection{Measurement of water activity (Aw)}

The measurement of water activity of the cookies at $17.5^{\circ} \mathrm{C}$ was conducted sixty-minutes after the baking process using an Aw analyzer (Aqua Lab Model Series 3TE, Decagon Devices, Inc., Pullman, WA) previously calibrated with a lithium chloride solution. The measurements were carried out four times.

\subsection{Sensory assessment}

The sensory analysis was carried out in the laboratory of sensory analysis at the Federal University of Paraná (PR), Brazil, in individual booths. The samples were coded randomly and were given to the panelists with one glass of water $(50 \mathrm{~mL})$ and a cream cracker savory biscuit, so the palate could be cleaned. The sensory evaluation was approved by the Federal University of Paraná Ethics Research Committee in accordance with the Resolution no 196 of the Brazilian National Health Council.

The panelists were divided into two different groups (one containing 58 people and the other 57), in a way that to each group corresponded only to one formulation of the cookie samples (SHIROSE and MORI, 1994). A total of 115 untrained taste panelists (17-55 years old; 69 males and 46 females), who declared themselves frequent consumers of soy-containing products, were recruited from the campus community at the Federal University of Paraná. In accordance with DUTCOSKY (2007) the number of panelists to assess the acceptance of food products should represent at least 100 consumers. A five-point hedonic scale was utilized in the analysis: 1 = Disliked Much (DM), 2 = Slightly
Disliked (SD), 3 = Indifferent (IN), 4 = Slightly Liked (SL), 5 = Liked Much (LM).

\subsection{Statistical analysis}

The results from the physicochemical evaluation were initially submitted to Levene's test to check for the homogeneity of the variances. As a second step, one-way analysis of variance (ANOVA) was carried out to determine the existence of statistical differences between the samples, followed by Tukey's HSD post-hoc parametric test, at $5 \%$ of significance (MONTGOMERY, 2000), using the software Statistica 7.0 (Stat Soft, Tulsa, OK, USA). A $P$ value $<0.05$ was considered significant.

The data from the sensory evaluation were submitted to the Goodman's test, a non-parametrical statistics, to check for differences in acceptance between the samples, at $5 \%$ of significance (SHIROSE; MORI, 1999). The acceptance index of the cookies was calculated by the percentage of respondents who indicated that they 'slightly liked' and 'liked much' the cookie samples.

\section{Results and discussion}

The results from the physicochemical analyses are presented in Table 1 together with some values of a cookie prepared with Brazilian nuts, one of the most important economic plants in the country. This comparison was drawn to show the differences and similarities among the samples produced. Statistically, there was difference $(\mathrm{P}<0.05)$ in all the parameters from the centesimal composition analyzed.

The protein content of the peanut and almond cookies was slightly higher than one for the Brazilian nuts cookie. Shrestha and Noomhorm (2002) obtained similar results (11.52\%) when they analyzed commercial cookies. On the other hand, Guilherme and Jokl (2005) determined lower protein contents in corn flour cookies (6.63-11.74\%). The same was observed by Scabio, Granato and Ferrari (2005) who developed orange bagasse cookie enriched with calcium and iron, which presented $5.40 \%$ of total protein. The consumption of $100 \mathrm{~g}$ of almond or peanut cookie would provide $16 \%$ of the total recommended daily recommended value of protein (DRV) for adults. FAO (1973) recommends the ingestion of 25-30 g/day of proteins for children aged 5 to 19 years old, which means that the consumption of $100 \mathrm{~g}$ of any cookie produced in this work would provide about $44 \%$ the DRV for those consumers.

The moisture content of the cookies produced was higher in the Brazilian nut cookie; however, the other parameters showed considerable similarity. Krüger et al. (2003) developed cookies with sodium caseinate which presented a content of moisture $86 \%$ higher than those of peanut and almond cookies. The same authors obtained higher contents of ashes $(2.43 \%)$ compared to the almond or peanut cookies. However, Guilherme and Jokl (2005) quantified lower values of total lipids (12.29-15.88\%) and ashe (0.88-1.26\%) in cookies elaborated with different corn flours.

To display the information 'source of iron' on the label, the final product must contain at least $15 \%$ (2.1 $\mathrm{mg})$ of the DRV for each $100 \mathrm{~g}$, and should be designated 'rich in iron' it should contain at 
least 30\% (4.2 mg) of the DVR (BRASIL, 1998). Notwithstanding, both almond and peanut cookies could be considered 'sources of iron' taking into consideration the Brazilian DRV for adults $(14 \mathrm{mg}$ ) and presented higher concentration of iron than the commercial cookie prepared with Brazilian nuts.

Water activity is defined as "free", "unbound", or "available water" in a system and this parameter measures the availability of water for deteriorative changes or microbial growth. This value is very important considering the development of a product, and it is an analysis of quality control and can be used for the determination of shelf-life (PHAM, 2001). The water activity is also considered as a good indicator of the baking process and therefore many cookie industries use it as a parameter of quality (CHEFTEL; CHEFTEL, 1977). The water activity of cookies does not have an established value due to the reason that it is related to the cookie ingredients. Mundt and Wedzicha (2007) analyzed biscuits and found Aw no higher than 0.40 and Ameur et al. (2007) quantified Aw ranging from $0.336 \pm 0.019$ to $0.452 \pm 0.031$ in cookies. Similar data were obtained in this work (Table 2). It shows that the cookie samples prepared with almond or peanut can be considered microbiological safe because under $A w=0.400$ there is no free water that can be used for microbial growth (PHAM, 2001).

There were some statistical differences $(\mathrm{P}<0.05)$ between the peanut and almond cookies in Aw, $C^{*}, L^{*}, a^{*}$, and $b^{*}$ parameters. High values of lightness $\left(L^{*}\right)$ and $b^{*}$ coordinate (browniness) of the cookies were expected due to the thermal process they were submitted. It is desirable that cookies present high intensity of brown color because regular cookies, the ones made from wheat flour and brown sugar, have high value of brow hue $\left(b^{*}\right)$. The total appearance of a cookie consists of visual structure, texture, and distributions of color on the top surface, and it is one of the many sensory factors to determine its purchase and consumption (HUTCHINGS, 1999).
Collins and Falasinnu (1977) evidenced that cookies elaborated with wheat bran and cellulose, in different concentrations, were darker than the control (wheat flour and without cellulose). Similar data was obtained by Vratanina and Zabik (1978) and Leelavathi and Rao (1993) using maize fibers and Silva (1997) utilizing Jatobá flour to develop new types of cookies with high content of fibers. Perez and Germani (2007) produced cookies with different concentrations of eggplant flour and obtained values of $L^{\star}$ (38.05-46.12), $a^{\star}$ (8.94-10.42) and $b^{*}(18.85-20.73)$. Similar results were obtained by Gouveia et al. (2007) measuring the color parameters $\left(L^{*}, a^{*}\right.$ and $\left.b^{*}\right)$ of traditional butter cookies enriched with Chlorella vulgaris biomass concluding that cookie color is directly related to the ingredients they are made from.

Goodman's test was used because there were two flavors of the same product (flavor was the only difference between the formulations), and so it was necessary to identify and quantify the difference of acceptance between the flavors of the cookies. As a result from the Goodman's test, it was obtained a value of $\mathrm{Y}^{2}=3.83$ and the tabled value for the existence of statistical difference between the samples was $\mathrm{X}^{2}=3.82$ (Shirose and Morei, 1994). It means that there was significant difference in acceptance, at $5 \%$ of probability, between the samples. Indeed, there is a significant subjectivity in the sensory evaluation when using consumers as panelists, which might explain the differences in the sensory acceptance of the cookies.

The acceptance indexes for the formulation $\mathrm{T} 1$ (peanut) and T2 (almond) - Figure 1 - were, 80 and 85\%, respectively, showing that the almond cookie was most preferred by the panelists and that both formulations presented satisfactory acceptance. Food acceptance is one of the main attributes that industries evaluate when a new product is processed because it influences consumers' purchase intention. Hence, the overall level of liking for the product must be as high as possible. To be successful in the market, food products should present, at least,

Table 1. Centesimal composition of almond, peanut and a marketed Brazilian nut cookie, in relation of $100 \mathrm{~g}$ of product.

\begin{tabular}{lccc}
\hline \multicolumn{1}{c}{ Parameter } & Peanut Cookie $(\mathrm{T} 1)$ & Almond Cookie (T2) & Brazilian nuts Cookie $^{*}$ \\
\hline Moisture $(\mathrm{g} / 100 \mathrm{~g})$ & $4.52 \pm 0.02 \mathrm{a}$ & $4.64 \pm 0.07 \mathrm{~b}$ & 2.50 \\
Protein $(\mathrm{g} / 100 \mathrm{~g})$ & $12.21 \pm 0.13 \mathrm{a}$ & $11.87 \pm 0.03 \mathrm{~b}$ & 10 \\
Lipids $(\mathrm{g} / 100 \mathrm{~g})$ & $22.41 \pm 0.08 \mathrm{a}$ & $27.53 \pm 0.15 \mathrm{~b}$ & 26 \\
Carbohydrates $(\mathrm{g} / 100 \mathrm{~g})$ & $59.40 \pm 0.10 \mathrm{a}$ & $54.23 \pm 0.12 \mathrm{~b}$ & 58 \\
Energy $(\mathrm{kcal} / 100 \mathrm{~g})$ & $488.12 \pm 1.53 \mathrm{a}$ & $513.54 \pm 2.07 \mathrm{~b}$ & 506 \\
Ashes $(\mathrm{g} / 100 \mathrm{~g})$ & $1.47 \pm 0.02 \mathrm{a}$ & $1.66 \pm 0.07 \mathrm{~b}$ & $\mathrm{~ns}$ \\
Iron $(\mathrm{mg} / 100 \mathrm{~g})$ & $3.18 \pm 0.22 \mathrm{a}$ & $2.73 \pm 0.10 \mathrm{~b}$ & 2.65 \\
\hline
\end{tabular}

${ }^{*}$ Nutritional values on the label ${ }^{* *}$ ns: not specified; The letters ' $a$ ' and ' $b$ ' in the same line represent different statistical results at $5 \%$ probability.

Table 2. Data from colorimetric and water activity analyses of cookies.

\begin{tabular}{lccccc}
\hline Cookie & \multicolumn{5}{c}{ Physical Parameters } \\
\cline { 2 - 5 } & $\mathrm{L}^{\star}$ & $\mathrm{a}^{\star}$ & $\mathrm{b}^{\star}$ & $\mathrm{C}^{\star}$ & $\mathrm{Aw}$ \\
\hline Almond & $36.06 \pm 0.60^{\mathrm{a}}$ & $15.11 \pm 0,11^{\mathrm{a}}$ & $27.84 \pm 0.47^{\mathrm{a}}$ & $31.68 \pm 0.43^{\mathrm{a}}$ & $0.426 \pm 0.0031^{\mathrm{a}}$ \\
Peanut & $42.67 \pm 0.55^{\mathrm{b}}$ & $14.21 \pm 0,065^{\mathrm{b}}$ & $29.30 \pm 0.45^{\mathrm{b}}$ & $32.67 \pm 0.19^{\mathrm{b}}$ & $0.467 \pm 0.0055^{\mathrm{b}}$ \\
p (Levene) & 0.862 & 0.399 & 0.563 & 0.683 & 0.450 \\
p (ANOVA) & $<0.001$ & $<0.001$ & 0.001 & 0.008 & $<0.001$ \\
\hline
\end{tabular}

Mean \pm standard deviation. The letters ' $a$ ' and ' $b$ ' in the same column represent different statistical results $(\mathrm{P}<0.05)$. 


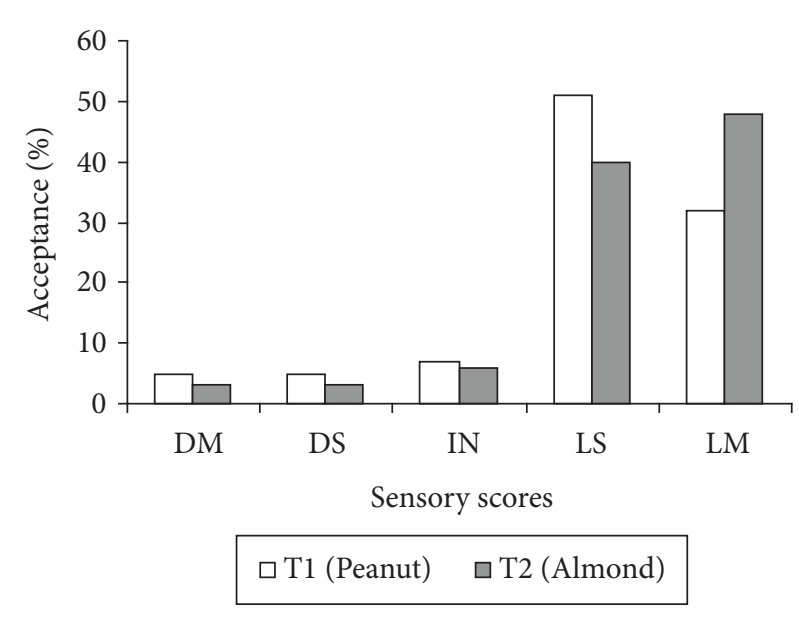

Figure 1. Acceptance percentage of the formulations T1 (peanut) and T2 (almond).

$70 \%$ of acceptance by potential consumers (DUTCOSKY, 2007). Therefore, the cookies produced with peanut or almond flour showed high potential to be explored by the industry. It is evident that it is a challenge to develop gluten-free cookies that can both indulge consumers' eating desire while also providing essential minerals. More studies must be carried out in order to test new ingredients and develop novel gluten-free products for the intolerants.

\section{Conclusion}

Both peanut and almond cookies presented a high degree of sensory acceptance, considerable content of proteins and lipids, and are sources of iron. The data suggest a possible commercial exploration of the produced cookies, so the number of these types of products could increase in the market, offering new nourishing options of consumption for gluten-intolerants.

\section{References}

ALVES, R. M. L.; GROSSMANN, M. V. E. Parâmetros de extrusão para produção de snacks de farinha de cara (Dioscorea alata). Ciência e Tecnologia de Alimentos, v. 22, n. 1, p. 32-38, 2002.

AMEUR, L. A. et al. Comparison of the effects of sucrose and hexose on furfural formation and browning in cookies baked at different temperatures. Food Chemistry, v. 101, n. 4, p. 1407-1416, 2007.

ASSOCIATION OF OFFICIAL ANALYTICAL CHEMISTS - AOAC. Official Methods of Analysis of AOAC International. Washington, 2000. 1094 p.

BILGIÇLI, N.; İBANOG, L. S.; HERKEN, E. N. Effect of dietary fiber addition on the selected nutritional properties of cookies. Journal of Food Engineering, v. 78, n. 1, p. 86-89, 2007.

BOCCIO, J.; MONTEIRO, J. B. Fortificación de alimentos con hierro y zinc: pros y contras desde un punto de vista alimenticio y nutricional. Revista de Nutrição, v. 17, n. 1, p. 71-78, 2004.

BRASIL. Ministério da Saúde. Secretaria Nacional de Vigilância Sanitária. Portaria no 31, de 13 de janeiro de 1998. Aprova o Regulamento Técnico referente a Alimentos Adicionados de Nutrientes Essenciais, constante do anexo desta Portaria. Diário Oficial da União, Brasília, 4 p. 13 de janeiro de 1998.

BRASIL. Ministério da Saúde. RDC n 263, de 22 de setembro de 2005: Aprova o "regulamento técnico para produtos de cereais, amidos, farinhas e farelos", constante do Anexo desta Resolução. Diário Oficial da União, Brasília, 5 p. 22 de setembro de 2005.

BUTT, M. S. et al. Bioavailability and storage stability of vitamin A fortificant (retinyl acetate) in fortified cookies. Food Research International, v. 40, n. 10, p. 1212-1219, 2007.

CAVALHEIRO, S. F. L. et al. Biscoito sabor chocolate com resíduos de soja, OKARA: teste efetivo com crianças em idade pré-escolar. Alimentos e Nutrição, v. 12, p. 11-14, 2001.

CHEFTEL, J. C.; CHEFTEL, H. Introduction à la biochimie et à la technologie des aliments. Paris: Lavoisier, 1977. 420 p.

COLLINS, J. L.; FALASINNU, G. A. Dietary fiber as an ingredient in cookies. Tennessee Farm and Home Science, v. 101, p. 21-24, 1977.

CREDIDIO, E. Alimentos Fortificados. Boletim Brasileiro de Nutrilogia, v. 1, n. 3, p. 1-3, 2005.

DUTCOSKY, S. D. Análise Sensorial de Alimentos. Curitiba: Champagnat, 2007. 210 p.

FOOD AND AGRICULTURE ORGANIZATION - FAO. Energy and protein requirements. Rome: World Health Organization of United Nations, 1973. Technical Report (Series 522).

GOUVEIA, L. et al. Chlorella vulgaris biomass used as colouring source in traditional butter cookies. Inovative Food Science \& Emerging Technologies, v. 8, n. 3, p. 433-436, 2007.

GUILHERME, F. F. P.; JOKL, L. Emprego de fubá de melhor qualidade protéica em farinhas mistas para produção de biscoito. Ciência e Tecnologia de Alimentos, v. 25, n. 1, p. 1-13, 2005.

HOFFPAUER, D. W.; WRIGHT, S. L. Enrichment of rice. In: MARSHALL, W. E.; WADSWORTH, A. (Eds.). Rice science and Technology. New York: Marshall Rekker, 1994.

HUTCHINGS, J. B. Food colour and appearance. Gaithersburg: Aspen Publishers, 1999.

INTERNATIONAL NUTRITIONAL ANEMIA CONSULTATIVE GROUP - INACG. Guidelines for the eradication of iron deficiency anemia. Washington: International Nutritional Anemia Consultative Group; Nutrition Foundation, 1977.

INSTITUTO ADOLFO LUTZ. Normas Analíticas do Instituto Adolfo Lutz: métodos químicos e físicos para análise de alimentos. Brasília, 2005.

KRÜGER, C. C. H. et al. Biscoitos tipo "cookie" e "snack" enriquecidos, respectivamente com caseína obtida por coagulação enzimática e caseinato de sódio. Ciência e Tecnologia de Alimentos, v. 23, n. 1, p. 81-86, 2003.

LEELAVATHI, K.; RAO, H. P. Development of high fiber biscuits using wheat bran. Journal of Food Science Technology, v. 30, n. 3, p. 187-191, 1993.

MARTIN, M. L. G. M. et al. Measuring colour appearance of red wines. Food Quality and Preference, v. 18, n. 6, p. 862-871, 2007.

MASON, J. B. et al. The Micronutrient Report: Current Progress and Trends in the Control of Vitamin A, Iodine, and Iron Deficiencies. Ottawa: Micronutrient Initiative, 2001, p. 314-320.

MATIAS, M. F. O. et al. Use of fibers obtained from the cashew (Anacardium ocidentale) and guava (Psidium guayava) fruits for enrichment of food products. Brazilian Archives of Biology and Technology, v. 48, p. 143-150, 2005. 
MONTGOMERY, D. C. Design and analysis of experiments. New York: Wiley, 2000.

MORETO, E. Processamento e Análise de biscoitos. São Paulo: Varela, 1999. 97 p.

MUNDT, S.; WEDZICHA, S. M. A kinetic model for browning in the baking of biscuits: effects of water activity and temperature. LWT Food Science and Technology, v. 40, n. 6, p. 1078-1082, 2007.

MURCH, S.; WALKER-SMITH, J. A imunologia da doença celíaca. In: Doença celíaca: Anais Nestlé. Suíça: Nestlé Nutrition Services, 1995. p. 18-25.

NEVES, L. S. Fermentado probiótico de suco de maçã. 2005. 97 f. Dissertação (Doutorado em Processos Biotecnológicos) - Setor de Biotecnologia, Universidade Federal do Paraná, Curitiba.

OSBORNE, D. R.; VOOGT, P. Análisis de los nutrientes de los alimentos. Zaragoza: Acribia, 1986. 258 p.

ÖZTÜRK, S. et al. Effects of brewer's spent grain on the quality and dietary fiber content of cookies. Journal of the Institute of Brewing, v. 108, n. 4, p. 23-27, 2002.

PARRA, C. D. Cada vez mais biscoitos. O \& G Alimentos, v. 72, p. 4, 2003

PEREZ, P. M. P.; GERMANI, R. Elaboração de biscoitos tipo salgado, com alto teor de fibra alimentar, utilizando farinha de berinjela (Solanum melongena, L.). Ciência e Tecnologia de Alimentos, v. 27, n. 1, p. 186-192, 2007.

PHAM, Q. T. Modelling thermal process: cooling and freezing. In: TIJSKENS, L. M. M.; HERTOG, M. L. A. T. A.; NICOLAI, B. M. (Eds.). Food process modeling. Cambridge: Woodhead Publishing Limited, 2001. p. 312-339.

SANTUCCI, M. C. C.; ALVIM, I. D.; FARIA, E. V. Efeito do enriquecimento de biscoitos tipo água e sal, com extrato de levedura (Saccharomyces sp.). Ciência e Tecnologia de Alimentos, v. 23, n. 3, p. 441-446, 2003.

SCABIO, A.; GRANATO, D.; FERRARI, R. A. Aplicação do bagaço de laranja na produção de biscoitos. In: SEMANA DE ENGENHARIA DE ALIMENTOS, 4., Ponta Grossa. Anais... Ponta Grossa: Universidade Estadual de Ponta Grossa, 2005. 2 p.

SHRESTHA, A. K.; NOOMHORM, A. Comparison of physico-chemical properties of biscuits supplemented with soy and Kinema flours. International Journal of Food Science and Technology, v. 37, n. 4 , p. $361-368,2002$.
SHIROSE, I.; MORI, E. E. M. Estatística aplicada à análise sensorial (Módulo 1). Campinas: ITAL, 1994. Manual técnico, 13.

SILVA, M. R. Caracterização química e nutricional da farinha de jatobá (Hymenaea stigonocarpa Mart.): desenvolvimento e otimização de produtos através de testes sensoriais afetivos. 1997. $154 \mathrm{f}$. Tese (Doutorado em Tecnologia de Alimentos) - Universidade Estadual de Campinas, São Paulo, 1997.

SILVA, M. A. et al. Uso de hidrolisado de pescado como suplemento protéico em biscoito de polvilho. In: ENCONTRO REGIONAL SUL DE CIÊNCIA E TECNOLOGIA DE ALIMENTOS, 9., 2007, Curitiba. Anais... Curitiba: Editar, 2007. p. 475-479.

SINDICATO DAS INDÚSTRIAS DE MASSAS ALIMENTÍCIAS E BISCOITOS NO ESTADO DE SÃO PAULO - SIMABESP. Estatística de produção de biscoitos no Brasil e no mundo. Disponível em: <http://www.simabesp.org.br/>. Acesso em: 26 de Março de 2008.

Tabela Brasileira de Composição de Alimentos - TACO. Campinas: Núcleo de Estudos e Pesquisas em Alimentação; Universidade Estadual de Campinas, 2006.

TORRES, M. A. A.; SATO, K.; LOBO, N. F. Efeito do uso de leite fortificado com ferro e vitamina $\mathrm{C}$ sobre os níveis de hemoglobina e condição nutricional de crianças menores de 2 anos. Revista de Saúde Pública, v. 29, n. 4, p. 301-307, 1995.

TORRES, M. A. A.; LOBO, N. F.; SATO, K. Fortificação do leite fluido na prevenção e tratamento da anemia carencial ferropriva em crianças menores de 4 anos. Revista de Saúde Pública, v. 30, n. 4, p. 350-357, 1996.

UNITED STATES DEPARTMENT OF AGRICULTURE - USDA. Composition of foods raw, processed, prepared. Estados Unidos, 2003. USDA National nutrient database for standard reference. Release 16. Nutrient data laboratory homepage. Disponível em: $<$ http://www.nal.usda.gov/fnis/foodcomp $>$. Acesso em: $25 \mathrm{de}$ Abril de 2005.

VRATANINA, D. L.; ZABIK, M. E. Dietary fiber sources for baked products: Bran in sugar snap cookies. Journal of Food Science, v. 43, n. 5, p. $1590-1594,1978$.

WALL, J. S.; HUEBNER, F. R. Adhesion and cohesion. In: CHERRY, J. P. (Ed.). Protein Functionality in Foods. Washington: American Chemical Society, 1981. p. 111.

WORLD HEALTH ORGANIZATION - WHO. Iron deficiency anaemia: assessment, prevention and control. Geneva: World Health Organization, 2008. A guide for programme managers. 